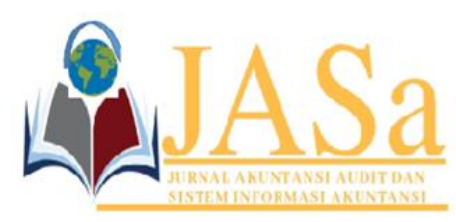

JASa (Jurnal Akuntansi, Audit dan Sistem Informasi Akuntansi)

Vol. 5 No.1/ April 2021

ISSN 2550-0732 print / ISSN 2655-8319 online

DOI;10.36555/jasa.v5i1.1486

\title{
THE EFFECT OF INFORMATION ASYMMETRY AND BUSINESS DIVERSIFICATION ON COST OF EQUITY CAPITAL
}

\author{
Nurul Intan Okci Pratiwi \\ Universitas Padjadjaran, Indonesia \\ nurul12032@mail.unpad.ac.id
}

\begin{abstract}
This study aims to examine the effect of information asymmetry and business diversification on capital in mining companies listed on the Indonesia Stock Exchange with a sample size of 14 companies for the 2017-2019 period. The data analysis is descriptive research with quantitative methods in the form of secondary data. Information asymmetry is measured by the bid-ask spread, which is the difference between the asking price and the company's stock offer price, and diversification is measured by the Herfindahl Index proxy to measure the number of segments owned by the company, while the cost of capital is measured using the Ohlson model. Hypothesis testing is performed using linear regression analysis to see the slightest effect of information asymmetry and diversification on the cost of equity capital. The results show that the research information asymmetry has a positive impact on equity capital, the higher the information that occurs related to company risk so that the company is riskier, causing investors to expect a higher level of invested shares, and business diversification has a big effect. has a positive impact on the cost of equity capital for companies that diversify their business, the higher the investment risk and the higher the cost of equity capital incurred by the company.
\end{abstract}

Keywords: Cost of Equity Capital, Diversification, Information Asymmetry.

\section{INTRODUCTION}

In carrying out its business activities, the company requires external funds, namely creditors and investors. The capital market is a medium for investment that can bring together those who provide funds with those who need funds. Companies usually issue shares or bonds that will be traded on the capital market to obtain funds from external parties. Investors entrust their funds to company management to carry out their business activities and later management will report their business activities by publishing financial reports (Setyaningrum, 2013). The financial report is a container of information for shareholders to find out the condition of the company that is run by management to measure the risk and return of investment funds given to the company.

Investors' expectation of the return on their investment is known as the cost of equity capital. The cost of equity capital is the rate of return desired by both investors and creditors. This cost of equity capital relates to the risk of investing in shares owned by the company (Ifonie, 2012). Investors aim to provide investment funds in companies to obtain a high rate of return from the shares that have been purchased (Ariani, 2016).

Cost of Equity Capital is a fee given by the company as a party that obtains funds from investors by selling shares (Hermuningsih, 2012). The cost of equity capital is the rate of return that investors are expected to receive in the future. The expected rate of 


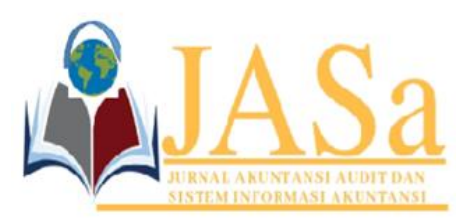

JASa (Jurnal Akuntansi, Audit dan Sistem Informasi Akuntansi)

Vol. 5 No.1/ April 2021

ISSN 2550-0732 print / ISSN 2655-8319 online

DOI; $10.36555 /$ jasa.v5i1.1486

return relates to the estimated risk faced, when a high-risk estimate causes investors to expect a high rate of return, the opposite is true because the estimated risk is directly proportional to the rate of return to be received (Setyaningrum, 2013).

The cost of equity capital can be influenced by several factors, one of which is information asymmetry. Information asymmetry is a condition in which the agent has more information about the company and the company's prospects in the future than the principal. (Rahmawati et al., 2012). The manager as management who wants to show good performance can be motivated to modify the financial statements to generate high profits as desired by the owner, this can be detrimental to investors (Barus \& Setiawati, 2015). It can be said that this information asymmetry occurs because of the difference in interests between management and investors.

This can cause the high information asymmetry that occurs in the capital market which can encourage companies to pay more to attract investors, while high information asymmetry will cause investors to want a higher rate of return than the invested shares (Dewi et al., 2017).

Agency Theory is a relationship that occurs between management and investors. Investors delegate their obligations to management such as managing the investment given, delegating authority, and making decisions (Anthony \& Govindaraja, 2005). This theory explains that management (internal) knows more information about the company's future goals than investors (Ariani, 2016).

Signaling Theory explains that information about the company is conveyed to users of financial statements such as the public, investors, and the government (Setyaningrum, 2013). By providing information or signals to users of financial statements, it is hoped that they can get a positive reaction from users of financial statements that can benefit the company. Delivery of this information is usually carried out by company management through the disclosure of annual reports.

Business diversification is one of the company's strategies to expand its business in improving financial performance. Diversification can be done using mergers, acquisitions by companies, to expand product lines, or open new branches or units. It aims to maximize the size and type of business so that company owners can obtain a high level of profit from the number of business segments they have (Dimarcia \& Krisnadewi, 2016).

Through diversification, companies can facilitate the allocation of working capital, both between divisions within one company and between companies within one corporation. In line with research conducted by (Kusumawardhani, 2018) that the more the diversification strategy is carried out by the company, the higher the cost of equity capital will be because the company will increase in-efficiency costs in allocating funds.

This phenomenon of the cost of equity capital occurs in several sectors of mining companies, including PT. Indo Tambangraya Megah Tbk (ITMG) and PT. Indika Energy Tbk (INDY), which experienced a decline in dividend payments per share for the 2019 financial year due to low commodity prices resulting in oversupply, this has affected the fundamental performance of mining sector issuers as well as the level of return desired by investors on their invested investment (Ariyanti, 2020). 


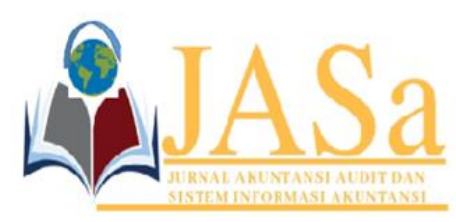

\author{
JASa (Jurnal Akuntansi, Audit dan Sistem Informasi Akuntansi) \\ Vol. 5 No.1/ April 2021 \\ ISSN 2550-0732 print / ISSN 2655-8319 online \\ DOI; $10.36555 /$ jasa.v5i1.1486
}

In this study, researchers took two factors that affect the cost of equity capital including information asymmetry and diversification. The cost of equity capital is influenced by information asymmetry, where information asymmetry discusses the problem of information inequality between the agent and the principal. Meanwhile, diversification discusses business development carried out by the company to expand its business segment.

The object of research is the problem to be studied. So the object of research in this study is information asymmetry, and diversification on cost of equity capital in mining companies listed on the Indonesian Stock Exchange in 2017-2019.

\title{
Hypothesis
}

Based on the description above, the hypothesis is proposed as follows:

$\mathrm{H}_{1} \quad$ : Information asymmetry had a positive impact on the cost of equity capital

$\mathrm{H}_{2}$ : Diversification had a positive impact on the cost of equity capital.

\section{METHODS}

The research method is a scientific way to obtain data for a specific purpose (Sugiyono, 2017). This study aims to test and analyze the effect of information asymmetry and diversification on the cost of equity capital. The data used is in the form of secondary data, namely quantitative data obtained from the official website of the Indonesia Stock Exchange and the websites of each company sampled in the form of annual reports of mining companies for the 2017-2019 period.

\section{Sample Determination Method}

The population in this study are mining companies listed on the Indonesia Stock Exchange (IDX) for the 2017-2019 period with the main and development groups. The sample is part of the criteria of a population (Sugiyono, 2017), The sample selection in this study uses a purposeful sampling method, which is based on certain criteria. The criteria set for sampling are as follows (1) Mining companies listed on the Indonesia Stock Exchange (IDX) for the period 2017-2019. (2) Mining companies that publish annual reports in a row for the 2017-2019 period and (3) Financial reports that are stated in the rupiah currency. Thus the sample in this study uses 14 companies that have met the criteria.

\section{Information Asymmetry}

Measurement of information asymmetry, using the bid-ask spread. The bid-ask spread is the difference between the ask and bid prices. The measurement scale is in the form of a ratio and the unit of measure is a percentage (\%). The measurement refers to research (Ariani, 2016), with the following formula:

Information:

$$
\text { SPREAD }_{\mathrm{i}, \mathrm{t}}=\frac{(\text { aski, } \mathrm{t}-\text { bidi, } \mathrm{t})}{((\text { aski, }+ \text { bidi,t }) / 2)} \times 100
$$

ask $_{\mathrm{i}, \mathrm{t}}=$ the highest ask price (offering price) for company i's shares that occurs on day $\mathrm{t}$ (on the publication date of the annual report) 


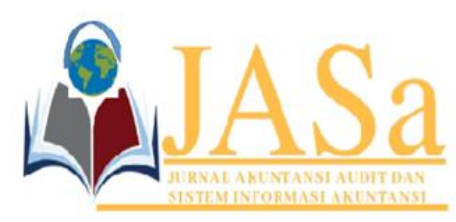

JASa (Jurnal Akuntansi, Audit dan Sistem Informasi Akuntansi)

Vol. 5 No.1/ April 2021

ISSN 2550-0732 print / ISSN 2655-8319 online

DOI;10.36555/jasa.v5i1.1486

bid $_{\mathrm{i}, \mathrm{t}}=$ The lowest bid price (asking price) for company i's shares that occurs on day $t$ (on the publication date of the annual report)

\section{Diversification}

Diversification measurement refers to research (Aryati \& Walansendouw Yoel Charisma, 2013) which is measured using the Herfindahl proxy. The index is calculated based on each business/business segment on the types of businesses or products produced. With the following formula:

Where HERFit is a revenue-based Herfindahl Index for a company (i) in a year (t). If the HERFit value is above 1 or equal to 1 then the company is a single segment, and if the value is below 1 or less than 1 then the company has more than one business segment. So that the smaller the HERFit value, the higher the level of diversification carried out by the company.

\section{Cost of Equity Capital}

The measurement of the cost of equity capital refers to research (Setiawan \& Daljono, 2014) which is measured using the Ohlson model calculation method with the following formula:

$$
\begin{aligned}
& r=(B t+(X t+1)-P t) / P t \\
& r \quad=\text { Cost Of Equity capital } \\
& B_{t}=\text { Book value per share for } t \\
& \text { period } \\
& \mathrm{P}_{\mathrm{t}} \quad=\text { share price in } \mathrm{t} \text { period } \\
& \mathrm{X}_{\mathrm{t}+1} \quad=\text { earnings per share for the } t+1 \\
& \text { period }
\end{aligned}
$$

\section{Research Model}

The analysis used in this research is multiple linear regression analysis and the classical assumption test. Multiple linear regression analysis is to see the effect of the independent variable on the dependent variable. In this analysis, it measures the relationship between two or more variables (Ghozali, 2011). While the classical assumption test of the regression model is carried out to assess whether this model is consistent or not.

\section{RESULTS AND DISCUSSION Variable Description}

Based on the results from table 1, it can be seen that the lowest, highest, average, and standard deviation of each variable each year with a total sample of 126 observational data from 14 companies for 3 years, namely in 2017, 2018, and 2019. For variables, The highest information asymmetry $\left(X_{1}\right)$ was in 2019 and 2017, which was 0.199 and the lowest was in 2019 , which was 0.113 . Whereas for the diversification 


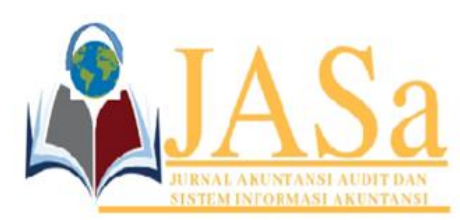

JASa (Jurnal Akuntansi, Audit dan Sistem Informasi Akuntansi)

Vol. 5 No.1/ April 2021

ISSN 2550-0732 print / ISSN 2655-8319 online

DOI;10.36555/jasa.v5i1.1486

variable $\left(X_{2}\right)$ the highest occurred in 2018 which was 1.029 and the lowest was in 2019 which was 0.563 .

Table 1

Descriptive Statistics

\begin{tabular}{|c|c|c|c|c|c|}
\hline & $\mathrm{N}$ & Minimum & Maximum & Mean & Std. Deviation \\
\hline $\begin{array}{l}\text { Information Asimmetry, } \\
2019\end{array}$ & 14 &, 113 & ,199 & , 16593 & ,028067 \\
\hline $\begin{array}{l}\text { Information Asimmetry, } \\
2018\end{array}$ & 14 & ,128 &, 187 & ,17121 & ,018820 \\
\hline $\begin{array}{l}\text { Information Asimmetry, } \\
2017\end{array}$ & 14 & ,128 & , 199 & , 16371 & ,026386 \\
\hline Diversification, 2019 & 14 &, 563 & ,991 & ,75736 & ,144791 \\
\hline Diversification, 2018 & 14 & ,603 & 1,029 & ,77779 & , 142958 \\
\hline Diversification, 2017 & 14 & ,617 & ,992 & ,82129 & ,135356 \\
\hline $\begin{array}{l}\text { Cost Of Equity Capital, } \\
2019\end{array}$ & 14 & ,129 & 21,587 & 5,48143 & 6,549020 \\
\hline $\begin{array}{l}\text { Cost Of Equity Capital, } \\
2018\end{array}$ & 14 & ,042 & 24,116 & 4,16157 & 6,441461 \\
\hline $\begin{array}{l}\text { Cost Of Equity Capital, } \\
2017\end{array}$ & 14 & ,151 & 29,585 & 4,89014 & 7,555077 \\
\hline Valid N (listwise) & 14 & & & & \\
\hline
\end{tabular}

Source: Output SPSS 2020

\section{Classic assumption test}

Before conducting further research, the research must first test the classical assumptions. In this study, the classic assumption test used was the normality test, where the normality test was the Asymp value. Sig. (2-tailed) $0.218>0.05$, which means the data is normally distributed. Furthermore, the autocorrelation test shows the DurbinWatson value of 1.592 where the value is between -2 and 2 , so it can be concluded that the regression model used is free from autocorrelation disorders.

\section{Multiple Linear Regression Analysis}

Table 2 Multiple Linear Regression Analysis

Coefficients $^{\mathrm{a}}$

\begin{tabular}{ccccccc}
\hline \multicolumn{7}{c}{ Standardized } \\
Model & \multicolumn{7}{c}{ Unstandardized Coefficients } & Coefficients & & \\
\hline 1 & B & Std. Error & Beta & t & Sig. \\
& (Constant) & 232,100 & 61,397 & & 3,780 &, 003 \\
& Total_X1 & 31,334 & 39,620 &, 483 & 2,358 &, 038 \\
& Total_X2 & 47,410 & 12,460 &, 780 & 3,805 &, 003 \\
\hline
\end{tabular}

a. Dependent Variable: Total_Y

Source: Output SPSS 2020

Submitted: November 24, 2020; Accepted: March 03, 2021; Revised: March 24, 2020; Published: April 24, 2021; Website: http://journalfeb.unla.ac.id/index.php/jasa 


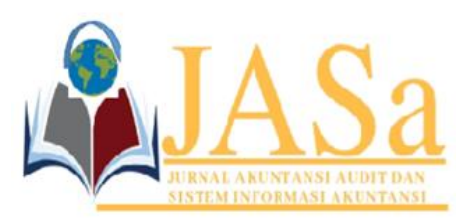

JASa (Jurnal Akuntansi, Audit dan Sistem Informasi Akuntansi)

Vol. 5 No.1/ April 2021

ISSN 2550-0732 print / ISSN 2655-8319 online

DOI; $10.36555 /$ jasa.v5i1.1486

$$
\begin{gathered}
Y=a+b 1 X 1+b 2 X \neg 2 \neg+e \\
Y=232,100+31,334 X 1+47,410 X 2+e
\end{gathered}
$$

The regression equation in Table 2 above explains that if there is no information asymmetry and there is no diversification or it can be said to be zero, then the cost of equity capital is worth 232,100 . The value of the coefficient b1 is 31,334 , indicating that information asymmetry has a positive effect on the cost of equity capital. So every time there is an increase in information asymmetry by unit, the cost of equity capital will increase by 31,334 . Conversely, if there is a decrease in information asymmetry by unit, the cost of equity capital will decrease by 31,334 . The b2 coefficient, which is 47,410 , shows that diversification has a positive effect on the cost of equity capital. Every time there is an increase in diversification by units, the capital cost of equity will increase by 47,410 . Conversely, if there is a decrease in diversification by units, the capital cost of equity will decrease by 47,410 .

\section{Partial Test (t-test)}

Based on the results of table 2, it can be seen that the results of the first hypothesis test which was carried out with the t-test partially obtained the $t$ value of $2.358>t \neg$ table of 1.97960 with a significance of $0.038<0.05$, then $\mathrm{Ho}$ is rejected and $\mathrm{H} 1$ is accepted. So it can be concluded that there is a positive effect of information asymmetry on the cost of equity capital.

The results of the second hypothesis test, which was carried out by partial t-test, were obtained a t-count of 3.805 $>t \rightarrow$ table of 1.97960 with a significance of $0.003<0.05$, so $\mathrm{Ho}$ is rejected and $\mathrm{H} 1$ is accepted. So it can be concluded that there is a positive effect of diversification on the cost of equity capital.

\section{Simultaneous Test (Test f)}

Table 3 Simultaneous Test (Test $f$ )

ANOVA $^{\mathrm{a}}$

\begin{tabular}{llrrrrr}
\hline Model & & Sum of Squares & \multicolumn{1}{c}{ Df } & Mean Square & \multicolumn{1}{c}{ F } & \multicolumn{1}{c}{ Sig. } \\
\hline 1 & Regression & 2955,908 & 2 & 1477,954 & 7,906 &, $007^{\mathrm{b}}$ \\
& Residual & 2056,330 & 11 & 186,939 & & \\
& Total & 5012,238 & 13 & & & \\
\hline
\end{tabular}

a. Dependent Variable: Total Y

b. Predictors: (Constant), Total_X2, Total_X1

Source: Output SPSS 2020

Based on data in Table 3 above, it can be seen that together with information asymmetry and diversification have a significant effect on the cost of equity capital. This can be proven from the calculated $\mathrm{F}$ value $(7,906)>\mathrm{F}$ table $(3.07)$ with a significance value of $0.007<0.05$, then $\mathrm{H} 0$ is rejected and $\mathrm{H} 1$ is accepted. It can be concluded that information asymmetry and diversification have a simultaneous effect on the cost of equity capital.

Submitted: November 24, 2020; Accepted: March 03, 2021; Revised: March 24, 2020; Published: April 24, 2021; Website: http://journalfeb.unla.ac.id/index.php/jasa 


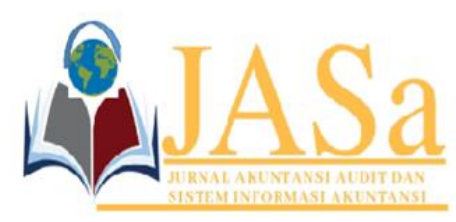

JASa (Jurnal Akuntansi, Audit dan Sistem Informasi Akuntansi)

Vol. 5 No.1/ April 2021

ISSN 2550-0732 print / ISSN 2655-8319 online

DOI; $10.36555 /$ jasa.v5i1.1486

\section{Coefficient of Determination}

Table 4 Coefficient of Determination Model Summaryb

\begin{tabular}{|c|c|c|c|c|c|c|c|c|c|}
\hline \multirow[b]{2}{*}{ Mode } & \multirow[b]{3}{*}{$B$} & \multirow{3}{*}{$\begin{array}{c}\mathrm{R} \\
\text { Square }\end{array}$} & \multirow{3}{*}{$\begin{array}{l}\text { Adjusted R } \\
\text { Square }\end{array}$} & \multirow{3}{*}{$\begin{array}{l}\text { Std. Error of } \\
\text { the } \\
\text { Estimate }\end{array}$} & \multicolumn{5}{|c|}{ Change Statistics } \\
\hline & & & & & R Square & $\mathrm{F}$ & & & Sig. F \\
\hline 1 & & & & & Change & Change & df1 & df2 & Change \\
\hline 1 & ,768a & ,590 & ,515 & 13,672565 &, 590 & 7,906 & 2 & 11 & ,007 \\
\hline
\end{tabular}

a. Predictors: (Constant), Total_X2, Total_X1

b. Dependent Variable: Total_Y

Source: Output SPSS 2020

Based on data in table 4 above, the influence of information asymmetry and diversification on the cost of equity capital is $59 \%$ and the rest is influenced by other factors not examined in this study.

\section{The Effect of Information Asymmetry on the Cost of Equity Capital}

Based on the results test, it is found that information asymmetry has a positive effect on the cost of equity capital. The results of this test are following the theory and previous research conducted by (Dewi et al., 2017) shows that information asymmetry has a positive effect on the cost of equity capital. Associated with agency theory, where investors who will invest their shares in the company want to expect a high rate of return, but this is related to information in the company in the form of the company's prospects only known by management, while investors do not fully know the information. Because if many investors know all the information contained in the company, investors will expect a high rate of return, and the costs borne by the company will be even greater in disclosing company information.

\section{The Effect of Diversification on the Cost of Equity Capital}

Based on the results test, it is found that diversification has a positive effect on the cost of equity capital. The results of this test are in line with the research (Kusumawardhani, 2018) that diversification is measured using the Herfindahl Index proxy and the number of business segments states that it has a positive effect on the cost of equity capital. Thus, the more diversified companies can reduce the risk of the company because related business diversification can reduce the dependence of a company on one other business activity, in other words, a company that has many business segments, the less risk it faces if one or more of the company's businesses fail. The company can still survive because it has other company businesses, this is related to investors investing their shares, when the company has low-risk investors will ask for a low rate of return and is directly proportional to the level of the cost of equity capital borne by the company. 


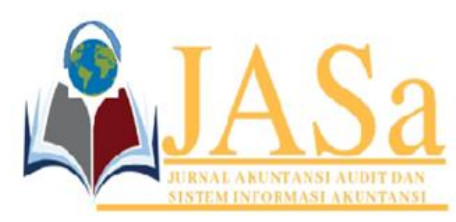

JASa (Jurnal Akuntansi, Audit dan Sistem Informasi Akuntansi)

Vol. 5 No.1/ April 2021

ISSN 2550-0732 print / ISSN 2655-8319 online

DOI; $10.36555 /$ jasa.v5i1.1486

\section{CONCLUSION}

Based on the research that has been done, it can be concluded that information asymmetry has a positive effect on the cost of equity capital. This shows that the higher the information asymmetry that occurs between the manager (agent) and the investor (principal) related to company risk. So the more risky the company is, causing investors to expect a higher rate of return from the shares invested, meaning that the cost of equity capital to be borne by the company is high. Whereas diversification has a positive effect on the cost of equity capital, this shows that the fewer companies that diversify their business or companies that develop their companies in a single segment, the higher the risk of investment and the high cost of equity capital by the company. Thus, the level of information asymmetry and business diversification has a relationship that is directly proportional to the level of the cost of equity capital.

\section{REFERENCES}

Anthony, R., \& Govindaraja, V. (2005). Sistem Pengendalian Manajemen (Buku 1). Penerbit Salemba Emoat.

Ariani, R. D. N. N. E. (2016). PENGARUH ASIMETRI INFORMASI , PENGUNGKAPAN MODAL INTELEKTUAL, DAN KUALITAS AUDIT TERHADAP BIAYA MODAL EKUITAS ( Studi pada Perusahaan LQ 45 yang Terdaftar di Bursa Efek Indonesia Tahun 2012-2014 ). Jurnal IImiah Mahasiswa Ekonomi Akuntansi (JIMEKA), 1(1), $149-157$.

Ariyanti, D. S. (2020). Emiten Tambang Siap Isi Dompet Investor, Tebar Dividen Rp9,43 Triliun.

Bisnis.Com.

https://market.bisnis.com/read/20200617/192/1253876/emiten-tambang-siap-isidompet-investor-tebar-dividen-rp943-triliun\#

Aryati, T., \& Walansendouw Yoel Charisma. (2013). Analisis Pengaruh Diversifikasi Perusahaan terhadap Manajemen Laba. Analisis Pengaruh Diversifikasi Perusahaan Terhadap Manajemen Laba, 9(2), 244-260. https://doi.org/10.14710/jaa.v9i2.5996

Barus, A. C., \& Setiawati, K. (2015). Pengaruh Asimetri Informasi, Mekanisme Corporate Governance dan Beban Pajak Tangguhan Terhadap Manajemen Laba. JWEM (Jurnal Wira Ekonomi Mikroskil), 5(1), 31-40. http://www.mikroskil.ac.id/ejurnal/index.php/jwem/article/view/223/146

Dewi, L. P. K. S., Wahyuni, M. A., \& Sujana, E. (2017). Pengaruh Asimetri Informasi, Pengungkapan Sukarela, Manajemen Laba dan Beta Saham Terhadap Cost of Equity Capital (Pada Perusahaan Perbankan yang Terdaftar di BEl Tahun 20132015). Jurusan Akuntansi Program S1, 07(01). https://ejournal.undiksha.ac.id/index.php/S1ak/article/viewFile/9385/6014

Dimarcia, N., \& Krisnadewi, K. (2016). Pengaruh Diversifikasi Operasi, Leverage Dan Kepemilikan Manajerial Pada Manajemen Laba. E-Jurnal Akuntansi, 15(3), 23242351.

Ghozali, I. (2011). Aplikasi Analisis Multivariate dengan Program SPSS19 (Edisi 5). Badan Penerbit Universitas Diponegoro.

Hermuningsih. (2012). Dampak Invesment Opportunity Set Terhadap Cost Of Equity 


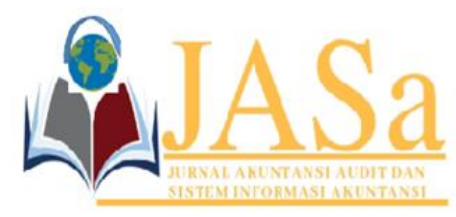

JASa (Jurnal Akuntansi, Audit dan Sistem Informasi Akuntansi)

Vol. 5 No.1/ April 2021

ISSN 2550-0732 print / ISSN 2655-8319 online

DOI;10.36555/jasa.v5i1.1486

Capital Dengan Diclosure Sebagai Variabel Mediasi. Doctoral Colloquium \& Conference FEB UGM, 28-29 November, November 2012, 1-16.

Ifonie, R. R. (2012). PENGARUH ASIMETRI INFORMASI DAN MANAJEMEN LABA TERHADAP COSTOF EQUITYCAPITAL PADAPERUSAHAAN REAL ESTATE YANG TERDAFTAR DI BURSA EFEK INDONESIA. JURNAL ILMIAH MAHASISWA AKUNTANSI, Vol 1(No 1).

Kusumawardhani, R. (2018). Pengaruh luas pengungkapan informasi, konsentrasi kepemilikan dan diversifikasi pada biaya modal ekuitas: studi pada perusahaan non-keuangan di Indonesia. Jurnal Siasat Bisnis, 22(2), 182-202. https://doi.org/10.20885/jsb.vol22.iss2.art5

Rahmawati, R., Suparno, Y., \& Qomariyah, N. (2012). Pengaruh Asimetri Informasi Terhadap Praktik Manajemen Laba pada Perusahaan Perbankan Publik yang Terdaftar di Bursa Efek Jakarta. The Indonesian Journal Of Accounting Research.

Setiawan, J. A., \& Daljono. (2014). PENGARUH KUALITAS AUDIT TERHADAP MANAJEMEN LABA DAN BIAYA MODAL EKUITAS. Jurnal Akuntansi Dan Keuangan, 16(1). https://doi.org/10.9744/jak.16.1.52-62

Setyaningrum, D. P. O. Z. (2013). PENGARUH KARAKTERISTIK PERUSAHAAN TERHADAP LUAS PENGUNGKAPAN SUKARELA DAN IMPLIKASINYA TERHADAP BIAYA MODAL EKUITAS (Studi Empiris pada Perusahaan Manufaktur yang terdaftar di Bursa Efek Indonesia Tahun 2011). Diponegoro Journal of Accounting, $\mathrm{O}(0)$, 318-331.

Sugiyono. (2017). Metode Penelitian Kuantitatif Kualitatif dan R\&D. Penerbit Alfabeta. 